\title{
Aksesibilitas Informasi, Sistem Pengendalian Internal, Pelatihan, dan Akuntabilitas Pengelolaan Dana Desa: Peran Teknologi Informasi
}

\author{
Alma Yumna Shafira ${ }^{1}$ \\ Fakultas Ekonomi dan Bisnis \\ Universitas Muhammadiyah \\ Yogyakarta, Indonesia
}

\author{
Evy Rahman Utami ${ }^{2}$ \\ Fakultas Ekonomi dan Bisnis \\ Universitas Muhammadiyah \\ Yogyakarta, Indonesia
}

\begin{abstract}
Surel : evy.rahman@umy.ac.id
ABSTRAK

Penelitian ini bertujuan untuk menguji pengaruh aksesibilitas informasi desa, sistem pengendalian internal, pelatihan perangkat desa terhadap akuntabilitas pengelolaan dana desa dengan pemanfaatan teknologi informasi sebagai variabel moderasi. Sampel dipilih dengan penggunaan metode proportional stratified random sampling. Teknik Analisis menggunakan regresi linier berganda dan regresi linier dengan uji nilai selisih mutlak. Hasil penelitian ini menunjukkan bahwa aksesibilitas informasi desa dan sistem pengendalian internal berpengaruh positif terhadap akuntabilitas pengelolaan dana desa, serta pemanfaatan teknologi informasi memperkuat pengaruh postif sistem pengendalian internal terhadap akuntabilitas pengelolaan dana desa. Namun, pelatihan perangkat desa tidak berpengaruh terhadap akuntabilitas pengelolaan dana desa.
\end{abstract}

Kata Kunci: Aksesibilitas; Sistem Pengendalian Internal; Pelatihan; Teknologi Informasi; Akuntabilitas; Dana Desa.

\section{Information Accessibility, Internal Control Systems, Training, and Accountability for Village Fund Management: The Role of Information Technology}

\begin{abstract}
This research aims to examine the effect of village information accessibility, internal control systems, village apparatus training on the accountability of village fund management with the use of information technology as a moderating variable. The sample was selected using the proportional stratified random sampling method. Analysis technique uses multiple linear regression and linear regression with the absolute different value test. The results of this research showed that the accessibility of village information and the internal control system have a positive effect on the accountability of village fund management, the use of information technology reinforces the positive influence of the internal control system on the accountability of village fund management. However, training for village officials has no effect on the accountability of village fund management.
\end{abstract}

Keywords: Accessibility, Internal Control System; Training; The Information Technology; Accountability; Village Fund.

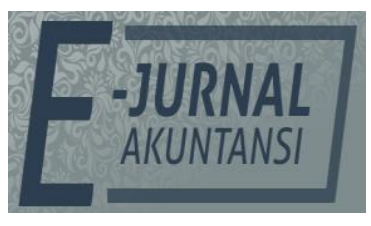

e-ISSN 2302-8556

Vol. 31 No. 4

Denpasar, April 2021 Hal. 1025-1040

DOI:

10.24843/EJA.2021.v31.i04.p18

PENGUTIPAN:

Shafira, A.Y., \& Utami, E.R.

(2021). Aksesibilitas

Informasi, Sistem

Pengendalian Internal,

Pelatihan, dan Akuntabilitas

Pengelolaan Dana Desa:

Peran Teknologi Informasi.

E-Jurnal Akuntansi, 31(4), 1025-1040

RIWAYAT ARTIKEL:

Artikel Masuk: 25 Februari 2021

Artikel Diterima:

21 April 2021

Artikel dapat diakses : https://ojs.unud.ac.id/index.php/Akuntansi/index 


\section{PENDAHULUAN}

Good governance pada abad ke 21 memerlukan adanya kepatuhan yang ketat dalam kaitannya dengan tanggung jawab akuntabilitas, informasi yang akurat, dan transparansi (Al-Tawil, 2016). Akuntabilitas merupakan alat yang digunakan sebagai kontrol dalam suatu organisasi dan mempunyai peran terkait penyelenggaraan kegiatan pemerintahan (Mada et al., 2017). Pemerintah desa merupakan suatu otoritas dalam kebijakan publik untuk mempertanggungjawabkan apa yang telah dilaksanakan dan dicapai kepada masyarakat (Judarmita \& Supadmi, 2017). Akuntabilitas tidak hanya diberikan kepada atasan, melainkan diberikan kepada masyarakat dalam bentuk informasi terkait laporan pertanggungjawaban atau realisasian anggaran desa (Dewi \& Gayatri, 2019). Di Indonesia kategori pengelolaan sumber daya masih sangat rendah, sehingga masih banyak penyimpangan yang mengakibatkan pada kerugian Negara, oleh karena itu kepercayaan masyarakat terhadap pemerintahan menjadi rendah (Rondonuwu, 2017).

Kepala Kejaksaan Negeri (Kejari) Wates Kulon Progo menyatakan bahwa terdapat kasus penggelapan dana desa dengan modus pembangunan fisik, pengadaan barang fiktif, dan lainnya yang dilakukan sejak tahun 2014 (Kuntadi, 2019). Berdasarkan hasil audit Badan Pemeriksaan Keuangan (BPK), Aparat Pengawas Internal Pemerintah (APIP), dan Badan Pengawas Keuangan dan Pembangunan (BPKP) terdapat kerugian Negara mencapai Rp 1,15 miliar (Kuntadi, 2019). Hasil audit BPK diharapkan tidak hanya digunakan sebagai sarana bentuk pertanggungjawaban pemerintah melainkan digunakan sebagai pertimbangan pemerintah dalam pengambilan keputusan (Kuntadi, 2019). Dalam pemeriksakan yang dilakukan oleh BPK masih terdapat permasalahan terkait dengan Sistem Pengendalian Internal (SPI). BPKP dan Inspektorat Kulon Progo mengembangkan maturitas penerapan Sistem Pengendalian Intern Pemerintahan (SPIP) dengan pemanfaatan teknologi yaitu E-SPIP untuk mempercepat proses penilaian yang diharapkan dapat mewujudkan good and clean governance di Kabupaten Kulon Progo (Humas BPKP DIY, 2019).

Pencapaian akuntabilitas pengelolaan dana desa membutuhkan keterbukaan akses informasi yang diperoleh publik baik informasi pengelolaan dana desa dan informasi laporan keuangan karena keterbukaan informasi akan meningkatkan kepercayaan publik (Fauziyah \& Handayani, 2017). Hasil penelitian Fikrian (2017), Fauziyah \& Handayani (2017), Hermanto (2019), Superdi (2017) membuktikan bahwa aksesibilitas berpengaruh positif terhadap akuntabilitas pengelolaan keuangan daerah. Akses informasi terkait kinerja entitas pemerintah yang dimiliki secara mudah memungkinkan publik untuk dapat mengidentifikasi dan menilai akuntabilitasnya baik atau buruk (Seda \& Tilt, 2020). Hasil penelitian Putri (2018), Azizah et al. (2015) menunjukkan bahwa tidak ada pengaruh antara aksesibilitas terhadap akuntabilitas pengelolaan keuangan daerah. Aksesibilitas merupakan kemudahan memperoleh informasi terkait dengan desa dan laporan keuangan desa sebagai bentuk akuntabilitas, pelaporan keuangan pengelolaan dipublikasikan melalui papan informasi desa sehingga perlunya untuk penelitian lebih lanjut terkait bentuk keterbukaan akses informasi untuk pemenuhan tanggungjawab publik. 
Sistem pengendalian internal yang berkaitan dengan terwujudnya tujuan organisasi sesuai dengan prinsip value for money yaitu efektivitas, efisiensi, ekonomisasi serta untuk mencapai keandalan dalam penyusunan laporan keuangan (Putri, 2018). Hasil penelitian Rosyidi (2018), Widyatama et al. (2017), Yesinia et al. (2018), Yudianto \& Sugiarti (2017), Rezkiyanti (2019) membuktikan bahwa hasil penelitian sistem pengendalian internal berpengaruh positif terhadap akuntabilitas pengelolaan dana desa. Sistem pengendalian internal yang sistematis sangat penting dan dapat membantu meningkatkan kepercayaan diantara pemangku kepentingan (Alam et al., 2019). Hasil penelitian Putri (2018), Cefrida (2014) menunjukkan bahwa tidak ada pengaruh antara sistem pengendalian internal terhadap akuntabilitas pengelolaan dana desa. Sistem pengendalian internal dapat tidak berpengaruh disebabkan organisasi belum menentukan adanya penentuan batas dan penilaian risiko dan belum menerapkan pemisahan tugas.

Pelatihan perangkat desa merupakan bentuk usaha untuk memperbaiki pengelolaan dana desa yang dilakukan tahun sebelumnya, meningkatkan kompetensi, dan produktivitas perangkat desa sehingga akan mempengaruhi akuntabilitas pengelolaan dana desa (Arjuna \& Putri, 2019). Hasil penelitian Yudhitaningsih \& Safrida (2018) menunjukan bahwa pelatihan berpengaruh negatif terhadap kinerja pemerintah desa dan Rangkuti (2018) menunjukan bahwa pelatihan tidak berpengaruh terhadap akuntabilitas kinerja pemerintah. Pelatihan yang diadakan tanpa didukung informasi terkait dengan kebijakan yang dirancang untuk mewujudkan pertanggungjawaban kepada publik tidak dapat berjalan dengan maksimal dalam mempengaruhi akuntabilitas (Rangkuti, 2018).

Pada penelitian ini menambahkan variabel pemanfaatan teknologi informasi sebagai variabel moderasi untuk memperkuat pengaruh antara sistem pengendalian internal terhadap akuntabilitas pengelolaan dana desa. Penambahan variabel kontijen hanya ditambahkan pada pengaruh sistem pengendalian internal terhadap akuntabilitas pengelolaan dana desa dikarenakan maturitas Sistem Pengendalian Internal Pemerintah (SPIP) dengan pemanfaatan teknologi dalam bentuk E-SPIP (Humas BPKP DIY, 2019). Pemanfaatan teknologi informasi merupakan sikap akuntan dalam mempercepat proses pembangunan nasional dan memfasilitasi tercapainya kesejahteraan publik dengan bantuan komputer dan internet (Rezkiyanti, 2019). Hasil penelitian yang dilakukan oleh Trisaputra (2013), Perdana (2018), Purbasari \& Yuniarta (2020), dan Rezkiyanti (2019) menunjukkan bahwa terdapat pengaruh positif antara pemanfaatan teknologi informasi terhadap akuntabilitas pengelolaan dana desa, sedangkan pada penelitian yang dilakukan oleh Karyadi (2019) menunjukkan bahwa tidak ada pengaruh antara pemanfaatan teknologi informasi terhadap akuntabilitas pengelolaan dana desa. Peran teknologi sangat penting dalam mempermudah dan mempercepat pekerjaan, namun masih terdapat penyalahgunaan manfaat dari peran teknologi. Penelitian ini mengembangkan model penelitian sebelumnya, karena teknologi mampu mempercepat dan efisien.

Tujuan penelitian ini untuk mengetahui pengaruh aksesibilitas informasi desa, sistem pengendalian internal, dan pelatihan perangkat desa terhadap akuntabilitas pengelolaan dana desa dengan pemanfaatan teknologi informasi sebagai variabel moderasi. Secara teoritis penelitian ini berguna untuk 
mengkonfirmasi teori stewardship mengenai pertanggungjawaban pengambilan keputusan yang dapat diminimalisir melalui aksesibilitas informasi desa, sistem pengendalian internal, pelatihan perangkat desa, dan pemanfaatan teknologi informasi. Teori stewardship didasarkan pada tingkah laku seseorang dan premis (Donaldson \& Davis, 1991). Teori stewardship merupakan teori yang memperlihatkan situasi bahwa manajemen tidak terpengaruh oleh tujuan-tujuan individu atau kepentingan tertentu tetapi lebih mementingkan kepentingan organisasi atau kepentingan bersama (Raharjo, 2007). Konsep dalam teori stewardship merupakan konsep kepercayaan pada pihak yang diberi wewenang sehingga pemerintah atau steward dalam suatu organisasi dicerminkan sebagai good steward (Bernstein et al., 2016). Pertanggungjawaban yang dilakukan pemerintah tersebut merupakan tanggungjawab yang harus dijalankan selaku steward dan sebagai bentuk pelayanan yang diberikan kepada pihak yang berkaitan dan yang berkepentingan (Haliah et al., 2015).

Aksesibilitas merupakan perpindahan informasi dari pemberi informasi kepada penerima informasi secara mudah, aman, nyaman, dan kecepatan yang semestinya (Fikrian, 2017). Penerapan akuntansi keuangan yang maksimal, memudahkan masyarakat dalam memperoleh informasi sehingga akan berpengaruh terhadap tingkat transparansi dan akuntabilitas keuangan daerah. Pemerintah berkewajiban untuk memberikan akses informasi terkait pengelolaan dana desa dan informasi lainnya yang akan dijadikan untuk pengambilan keputusan serta untuk mendorong akuntabilitas pemerintahan. Kemudahan akses yang diperoleh masyarakat akan meningkatkan kepercayaan mereka terhadap pemerintah desa. Penelitian yang dilakukan oleh Fauziyah \& Handayani (2017), Fikrian (2017), Superdi (2017) menunjukkan adanya pengaruh positif antara aksesibilitas terhadap akuntabilitas pengelolaan keuangan daerah. Berdasarkan penjelasan, peneliti mengembangkan hipotesis sebagai berikut.

$\mathrm{H}_{1}$ : Aksesibilitas informasi desa berpengaruh positif terhadap akuntabilitas pengelolaan dana desa.

Sistem pengendalian internal merupakan sistem yang ditetapkan untuk digunakan dalam menjalankan program seperti pembentukan struktur dalam organisasi dan metode yang dibutuhkan untuk mengkoordinasikan kegiatan pemerintah (Prayoga, 2017). Peraturan Pemerintah Nomor 60 Tahun 2008 menyebutkan sistem pengendalian internal adalah suatu bentuk usaha dan kegiatan yang dikerjakan oleh seluruh bagian organisasi untuk mewujudkan tujuan organisasi sesuai prinsip value for money yang dapat berpengaruh pada program-program pemerintah dan akan berdampak pada akuntabilitas (Yesinia et al., 2018). Sistem pengendalian internal merupakan salah satu penilaian berupa pengawasan dalam pengelolaan keuangan. Sistem pengendalian internal suatu pemerintah yang baik maka fungsi dan tugas pemerintah dapat berjalan sesuai prinsip value for money yang kemudian akan meningkatkan pertanggungjawaban pemerintah atas program yang telah dijalankan. Penelitian yang dilakukan oleh Rosyidi (2018), Widyatama et al. (2017), Yesinia et al. (2018), Yudianto \& Sugiarti (2017), Rezkiyanti (2019) menunjukkan adanya pengaruh antara sistem pengendalian internal terhadap akuntabilitas pengelolaan dana desa. Berdasarkan penjelasan, peneliti mengembangkan hipotesis sebagai berikut: 
$\mathrm{H}_{2}$ : Sistem pengendalian internal berpengaruh positif terhadap akuntabilitas pengelolaan dana desa.

Pelatihan adalah bentuk usaha yang dilakukan untuk memperbaiki kinerja seseorang yang berkaitan dengan tanggungjawab atas pekerjaan tersebut (Hasanah \& Sururi, 2018). Hasil penelitian Arjuna \& Putri (2019), menunjukkan pelatihan berpengaruh terhadap akuntabilitas kinerja pegawai karena pelatihan sangat penting untuk meningkatkan kompetensi dan kinerja karena pelatihan dapat meningkatkan nilai tambah sumber daya manusia dan produktif dalam melakukan kegiatan. Sumber daya manusia merupakan salah satu aset dalam organisasi atau instansi yang memiliki peran utama dalam mengembangkan organisasi. Dalam mengoptimalkan program kegiatan yang telah ditetapkan oleh organisasi maka dibutuhkan sumber daya yang memiliki kompentensi dan keterampilan yang baik (Julianry et al., 2017). Oleh karena itu organisasi membutuhkan cara dalam meningkatkan kompetensi dan keterampilan aparat desa dengan pelatihan. Penerapan pelatihan tersebut sejalan dengan good governance yang mana aparat pemerintahan harus menerapkan aspek-aspek fungsionalnya secara efisien dan efektif dalam rangka mencapai tujuan. Tujuan diadakannya pelatihan yaitu untuk mendapatkan perangkat desa yang memiliki sikap, keterampilan, pengetahuan, dan kemampuan yang baik untuk melaksanakan tanggungjawab mereka dalam bekerja. Sehingga apabila produktifitas kerja tinggi maka akuntabilitas pengelolaan dana desa yang akan dihasilkan semakin baik. Berdasarkan penjelasan, peneliti mengembangkan hipotesis sebagai berikut.

$\mathrm{H}_{3}$ : Pelatihan perangkat desa berpengaruh positif terhadap akuntabilitas pengelolaan dana desa.

Pemanfaatan teknologi digunakan untuk mempermudah mengolah data menjadi sebuah informasi yang digunakan untuk pengambilan keputusan (Trisaputra, 2013). Pemanfaatan teknologi informasi mempermudah dalam melakukan pengawasan terhadap program-program yang telah dijalankan oleh pemerintah desa secara lebih cepat dan efisien (Abbaszadeh et al., 2019). Perangkat desa yang memanfaatkan teknologi informasi dengan baik maka akan mempengaruhi maksimalnya program-program pemerintah yang akan dijalankan dan akan berpengaruh terhadap pertanggungjawaban yang diberikan kepada publik sehingga lebih mengedepankan kepentingan publik (Rezkiyanti, 2019). Tercapainya keberhasilan suatu organisasi dapat dilakukan melalui sistem pengendalian internal yang sesuai rencana, metode, prosedur, dan kebijakan yang telah dirancang. Oleh sebab itu semakin tinggi pemahaman perangkat desa terhadap sistem pengendalian internal dan didorong semakin tinggi pemanfaatan teknologi informasi dapat mempermudah dalam melakukan pengawasan terhadap pengelolaan dana desa sehingga akuntabilitas pengelolaan dana desa akan semakin baik. Berdasarkan penjelasan, peneliti mengembangkan hipotesis sebagai berikut.

$\mathrm{H}_{4}$ : Pemanfaatan teknologi informasi memperkuat pengaruh positif antara sistem pengendalian internal terhadap akuntabilitas pengelolaan dana desa 


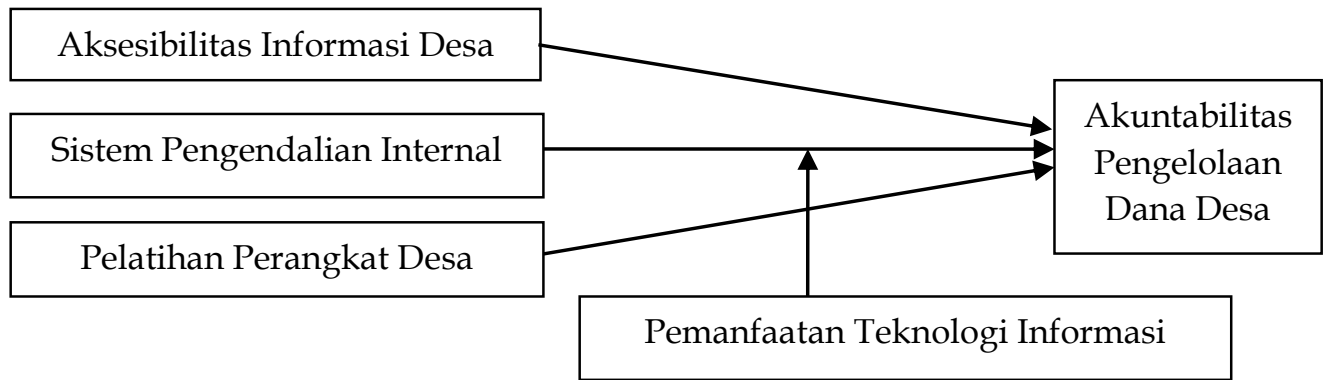

Sumber: Data Penelitian, 2020

\section{METODE PENELITIAN}

Penelitian ini dilakukan dengan menggunakan pendekatan kuantitatif dengan data yang bersumber dari data primer. Penelitian ini dilaksanakan di pemerintahan desa, Kabupaten Kulon Progo. Populasi dalam penelitian ini adalah pemerintah desa di Kabupaten Kulon Progo dengan subjek penelitian adalah perangkat desa. Dalam pengambilan sampel, penelitian ini menggunakan teknik proportional stratified random sampling, yaitu merupakan teknik pengambilan sampel berdasarkan atas pembagian populasi menjadi segmen-segmen penting, kemudian subjek diambil menurut proporsi terhadap jumlah awal mereka dalam populasi (Supardi, 1993). Kriteria yang digunakan yaitu pemerintahan desa dengan pembagian proporsi masing-masing kategori desa $40 \%$ berdasarkan Indeks Desa Membangun (IDM) yaitu kategori desa mandiri, maju, dan berkembang. Definisi operasional disajikan dalam Tabel 1, berikut.

Metode pengumpulan data menggunakan kuesioner dengan skala likert 15. Skala tersebut yaitu: 1) Sangat Tidak Setuju (STS), 2) Tidak Setuju (TS), 3) Netral $(\mathrm{N}), 4)$ Setuju (S), dan 5) Sangat Setuju (SS). Teknik analisis data yang digunakan dalam penelitian ini adalah analisis regresi linier berganda dan analisis regresi uji nilai selisih mutlak, dengan tahapan yang pertama yaitu statistik deskriptif, selanjutnya uji kualitas instrument, uji asumsi klasik, analisis regresi linier berganda dan analisis regresi uji nilai selisih mutlak, pengujian hipotesis melalui uji koefisien determinasi (Adjusted $R$ Square) dan uji signifikansi parsial (Uji t). Uji regresi linier berganda digunakan untuk mengetahui hubungan variabel independen dengan variabel dependen. Hipotesis keempat menggunakan uji regresi linier dengan uji nilai selisih mutlak. Menurut Ghozali (2005) uji nilai selisih mutlak merupakan persamaan regresi linier dimana dalam persamaannya mengandung unsur selisih mutlak variabel independen dengan variabel moderasi (Susanti \& Wardiningsih, 2014). Persamaan regresi berganda dalam penelitian ini adalah sebagai berikut.

Model 1

$y=\alpha+\beta_{1} \mathrm{AID}+\beta_{2} \mathrm{SPI}+\beta_{3} \mathrm{PPD}+\varepsilon$

Model 2

$y=\alpha+\beta_{1}$ SPI $+\beta_{2} M_{0}+\beta_{3}\left|S P I-M_{O}\right|+\varepsilon$

Keterangan:

$\mathrm{Y}=$ Akuntabilitas Pengelolaan Dana Desa

$\alpha \quad=$ Konstanta

$\beta \quad=$ Koefisien regresi linier $\mathrm{X}$ 


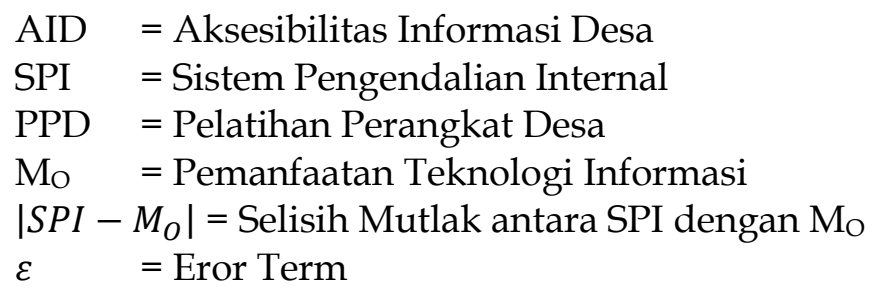

Tabel 1. Ringkasan Indikator Masing-Masing Variabel

\begin{tabular}{|c|c|c|}
\hline Variabel & Indikator & \multirow{2}{*}{$\frac{\text { Kuesioner }}{\text { Mada et al (2017) }}$} \\
\hline Akuntabilitas & Kejujuran dan keterbukaan informasi & \\
\hline Pengelolaan & 2. Kepatuhan dalam pelaporan & \\
\hline \multirow[t]{3}{*}{ Desa } & 3. Kesesuaian prosedur & \\
\hline & 4. Kecukupan informasi & \\
\hline & 5. Ketepatan penyampaian laporan & \\
\hline Aksesibilitas & 1. Keterbukaan & Astuti (2019) \\
\hline Informasi Desa & $\begin{array}{l}\text { 2. Kemudahan } \\
\text { 3. Accesible }\end{array}$ & \\
\hline Sistem Pengendalian & 1. Lingkungan pengendalian & Rezkiyanti (2019) \\
\hline \multirow{3}{*}{ Internal } & 2. Penilaian risiko & \\
\hline & 3. Kegiatan pengendalian & \\
\hline & 4. Informasi & \\
\hline & 5. Komunikasi & \\
\hline \multirow{5}{*}{$\begin{array}{l}\text { Pelatihan Perangkat } \\
\text { Desa }\end{array}$} & 2. Meningkatkan keterlambatan & (2019) \\
\hline & $\begin{array}{l}\text { 3. Meningkatkan antisipasi kecelakaan } \\
\text { kerja }\end{array}$ & \\
\hline & 4. Meningkatkan produktivitas & \\
\hline & 5. Meningkatkan penyelesaian masalah & \\
\hline & 6. Meningkatkan semangat kerja & \\
\hline \multirow{4}{*}{$\begin{array}{l}\text { Pemanfaatan } \\
\text { Teknologi Informasi }\end{array}$} & 1. Software pendukung & Rezkiyanti (2019) \\
\hline & 2. Ketersediaan jaringan internet & \\
\hline & 3. Dimanfaatkan sesuai ketentuan & \\
\hline & Proses terkomputerisasi & \\
\hline
\end{tabular}

Sumber: Data Penelitian, 2020

Akuntabilitas pengelolaan dana desa didefinisikan sebagai Kewajiban menyampaikan pertanggungjawaban kinerja seseorang atau organisasi kepada pihak yang memiliki hak untuk menilai keseuaian pertanggungjawaban terhadap pengelolaannya (Fajri et al., 2015). Aksesibilitas informasi desa didefinisikan sebagai kemudahan bagi seseorang untuk mendapatkan informasi, seperti informasi terkait pengelolaan dana desa, laporan keuangan ataupun informasi lainnya yang berguna bagi pihak berkepentingan (Fikrian, 2017). Sistem pengendalian internal didefinisikan sebagai proses yang dipengaruhi oleh pimpinan untuk mencapai efektivitas, efisiensi, dan kepatuhan pada peraturan perundangan serta keandalan dalam penyajian laporan keuangan (Yesinia et al., 2018). Pelatihan perangkat desa didefinisikan sebagai pembelajaran yang dapat memperbaiki kondisi sebelumnya dan dapat meningkatkan kemampuan dalam melaksanakan pekerjaan (Hasanah \& Sururi, 2018). Pemanfaatan teknologi informasi didefinisikan sebagai sikap seorang akuntan dalam memanfaatkan teknologi untuk meningkatkan kinerja dan penyelesaian tugas dengan peran 
teknologi sehingga pelayanan publik dapat tersampaikan dengan cepat dan mudah (trisaputra, 2013).

\section{HASIL DAN PEMBAHASAN}

Lokasi penelitian dilaksanakan di Pemerintahan Desa Kabupaten Kulon Progo dengan jumlah pemerintahan desa sebanyak 87 desa, peneliti mengambil pemerintahan desa sebagai sampel dengan jumlah 35 pemerintahan desa. Lokasi yang peneliti ambil dengan didasarkan atas Indeks Desa Membangun (IDM) yang terdapat di Kabupaten Kulon Progo. IDM dikembangkan berdasarkan konsepsi bahwa untuk menuju desa yang maju dan mandiri perlu kerangka kerja pembangunan dalam aspek sosial, ekonomi, dan ekologi serta menjaga potensi serta kemampuan desa untuk mensejahterakan kehidupan desa (Kementerian Desa Pembangunan Daerah Tertinggal dan Transmigrasi, 2020).

Responden dalam penelitian ini adalah perangkat desa di pemerintahan desa Kabupaten Kulon Progo. Ringkasan pengiriman serta pengembalian kuesioner disajikan dalam Tabel 2, berikut.

Tabel 2. Ringkasan Pengiriman dan Pengembalian Kuesioner

\begin{tabular}{lcc}
\hline \multicolumn{1}{c}{ Keterangan } & Jumlah & Presentase \\
\hline Kuesioner yang dikirim & 245 & $100 \%$ \\
Kuesioner yang Kembali & 220 & $89,8 \%$ \\
Kuesioner yang tidak Kembali & 25 & $10,2 \%$ \\
Kuesioner yang tidak dapat diolah & 10 & $4,08 \%$ \\
Kuesioner yang kembali dan dapat diolah & 210 & $85,72 \%$ \\
\hline
\end{tabular}

Sumber: Data Penelitian, 2020

Berdasarkan Tabel 2, dapat diketahui bahwa terdapat 10 kuesioner yang tidak dapat diolah karena terdapat beberapa point pernyataan yang tidak diisi oleh responden, sehingga kuesioner yang digunakan dan dapat diolah adalah sebanyak 210 kuesioner. Hasil statistik deskriptif disajikan dalam tabel 3 berikut.

Pada Tabel 3, menunjukkan bahwa data responden berjumlah 210 responden. Seluruh variabel menunjukan bahwa mean aktual $>$ mean teoritis. Artinya, perangkat desa di Kabupaten Kulon Progo menilai pengaruh variabelvariabel tersebut adalah tinggi. Pada masing-masing kategori desa berdasarkan Indeks Desa Membangun (IDM) yaitu desa mandiri, maju, dan berkembang menunjukan seluruhnya bahwa mean aktual $>$ mean teoritis. Artinya, perangkat desa di Kabupaten Kulon Progo menilai pengaruh variabel-variabel tersebut adalah tinggi.

Penilaian terhadap variabel aksesibilitas informasi desa pada responden desa berkembang memiliki pengetahuan yang lebih luas dibandingkan dengan desa maju dan berkembang. Penilaian terhadap variabel sistem pengendalian internal responden desa mandiri memiliki pengetahuan yang lebih luas dibandingkan dengan desa maju dan berkembang. Penilaian terhadap variabel pelatihan perangkat desa pada responden desa berkembang memiliki pengetahuan yang lebih luas dibandingkan dengan desa maju dan mandiri. Penilaian terhadap variabel pemanfaatan teknologi informasi responden desa berkembang memiliki pengetahuan yang lebih luas dibandingkan dengan desa maju dan mandiri. Penilaian terhadap variabel akuntabilitas pengelolaan dana 
desa, responden desa mandiri memiliki pengetahuan yang lebih luas dibandingkan dengan desa maju dan berkembang.

Tabel 3. Hasil Uji Statistik Deskriptif

\begin{tabular}{|c|c|c|c|c|c|c|c|c|c|}
\hline & \multirow{2}{*}{$\begin{array}{c}\text { Kategori } \\
\text { Desa (IDM) }\end{array}$} & \multirow[t]{2}{*}{$\mathrm{N}$} & \multicolumn{3}{|c|}{ Kisaran Teoritis } & \multicolumn{3}{|c|}{ Kisaran Aktual } & \multirow{2}{*}{$\begin{array}{l}\text { Std. } \\
\text { Deviation }\end{array}$} \\
\hline & & & Min & $\operatorname{Max}$ & Mean & Min & Max & Mean & \\
\hline \multirow[t]{4}{*}{ AID } & Mandiri & 14 & 3 & 15 & 9 & 10 & 15 & 12,2143 & 1,88837 \\
\hline & Maju & 89 & 3 & 15 & 9 & 8 & 15 & 13,1011 & 1,58863 \\
\hline & Berkembang & 107 & 3 & 15 & 9 & 10 & 15 & 13,1495 & 1,32326 \\
\hline & $\begin{array}{l}\text { Sampel } \\
\text { Keseluruhan }\end{array}$ & 210 & 3 & 15 & 9 & 8 & 15 & 13,0667 & 1,49171 \\
\hline \multirow[t]{4}{*}{ SPI } & Mandiri & 14 & 8 & 40 & 24 & 26 & 40 & 35,7143 & 3,68841 \\
\hline & Maju & 89 & 8 & 40 & 24 & 29 & 40 & 34,7303 & 3,29174 \\
\hline & Berkembang & 107 & 8 & 40 & 24 & 30 & 40 & 35,3084 & 3,13655 \\
\hline & $\begin{array}{l}\text { Sampel } \\
\text { Keseluruhan }\end{array}$ & 210 & 8 & 40 & 24 & 26 & 40 & 35,0905 & 3,24095 \\
\hline \multirow[t]{4}{*}{ PPD } & Mandiri & 14 & 6 & 30 & 18 & 20 & 30 & 24,6429 & 2,95107 \\
\hline & Maju & 89 & 6 & 30 & 18 & 18 & 30 & 24,5506 & 3,08225 \\
\hline & Berkembang & 107 & 6 & 30 & 18 & 18 & 30 & 24,8879 & 2,69635 \\
\hline & $\begin{array}{l}\text { Sampel } \\
\text { Keseluruhan }\end{array}$ & 210 & 6 & 30 & 18 & 18 & 30 & 24,7286 & 2,87335 \\
\hline \multirow[t]{4}{*}{ PTI } & Mandiri & 14 & 7 & 35 & 21 & 26 & 35 & 31 & 2,74563 \\
\hline & Maju & 89 & 7 & 35 & 21 & 24 & 35 & 30,0787 & 3,15589 \\
\hline & Berkembang & 107 & 7 & 35 & 21 & 24 & 35 & 30,3084 & 3,05426 \\
\hline & $\begin{array}{l}\text { Sampel } \\
\text { Keseluruhan }\end{array}$ & 210 & 7 & 35 & 21 & 24 & 35 & 30,2571 & 3,07336 \\
\hline \multirow[t]{4}{*}{ APDD } & Mandiri & 14 & 5 & 25 & 15 & 20 & 25 & 23,5714 & 1,50457 \\
\hline & Maju & 89 & 5 & 25 & 15 & 18 & 25 & 22,1236 & 2,10961 \\
\hline & Berkembang & 107 & 5 & 25 & 15 & 17 & 25 & 22,6355 & 2,09398 \\
\hline & $\begin{array}{l}\text { Sampel } \\
\text { Keseluruhan }\end{array}$ & 210 & 5 & 25 & 15 & 17 & 25 & 22,4810 & 2,09399 \\
\hline
\end{tabular}

Sumber: Data Penelitian, 2020

Pada pernyataan mengenai variabel Aksesibilitas Informasi Desa (AID), Sistem Pengendalian Internal (SPI), Pelatihan Perangkat Desa (PPD), Pemanfaatan Teknologi Informasi (PTI), dan Akuntabilitas Pengelolaan Dana Desa (APDD), keseluruhan variabel lolos uji kualitas instrument yaitu uji validitas dan reliabilitas serta lolos uji asumsi klasik yaitu uji normalitas, heteroskedastisitas, dan multikolinearitas.

Pada Tabel 4, menunjukan hasil analisis regresi linier berganda, maka model persamaan regresi linier berganda dapat dirumuskan adalah sebagai berikut.

$$
\mathrm{APDD}=7,379+0,290 \text { AID + 0,365 SPI - 0,061 PPD }+\varepsilon
$$

Pada Tabel 4, menunjukkan nilai Adjusted $R$ Square sebesar 0,448 artinya variabel Aksesibilitas Informasi Desa (AID), Sistem Pengendalian Internal (SPI), Pelatihan Perangkat Desa (PPD) mampu menjelaskan variabel Akuntabilitas Pengelolaan Dana Desa (APDD) sebesar 44,8\% dan sisanya yaitu 55,2\% dipengaruhi oleh variabel lain yang tidak masuk dalam model penelitian. 
Dari Tabel 4, dapat disimpulkan bahwa $\mathrm{H}_{1}$ terdukung yang berarti bahwa aksesibilitas informasi desa berpengaruh positif terhadap akuntabilitas pengelolaan dana desa. Pemerintah desa di Kabupaten Kulon Progo dalam meningkatkan aksesibilitas informasi desa melakukan beberapa tindakan dengan mempemudah akses media informasi seperti papan informasi desa, surat kabar atau website dan forum aspirasi Badan Pemeriksa Keuangan (BPK). Kemudahan akses media informasi yang diperoleh masyarakat terkait pengelolaan dana desa merupakan bentuk pemenuhan hak publik. Kemudahan akses media informasi didukung oleh keterbukaan informasi yang diberikan oleh pemerintah desa. Kemudahan akses informasi yang diperoleh masyarakat akan memberikan presepsi yang baik dan menghilangkan kecurigaan masyarakat terkait dengan akuntabilitas pengelolaan dana desa di Pemerintahan Desa Kabupaten Kulon Progo sehingga akuntabilitas pengelolaan dana desa akan semakin baik. Hasil yang signifikan ini menunjukan bahwa Pemerintahan Desa di Kabupaten Kulon Progo memberikan prespektif bahwa untuk mewujudkan pertanggungjawaban atas pengambilan keputusan yang baik pada pengelolaan dana desa yaitu dengan memberikan aksesibilitas informasi desa yang mudah diperoleh dan terbuka kepada publik, sehingga kemudahan akses yang diperoleh publik akan meningkatkan kepercayaan publik atas keputusan pertanggungjawaban pemerintah. Hal ini sejalan dengan penelitian Fauziyah \& Handayani (2017), Superdi (2017), Hermanto (2019), dan Fikrian (2017). Analisis Regresi Linier Berganda dan regresi linier uji nilai selisih mutlak diolah dengan bantuan software SPSS Statistik 22 dengan hasil yang dapat dilihat pada Tabel 4.

Tabel 4. Uji Hipotesis

\begin{tabular}{cccc}
\hline Variabel & Unstandardized Coefficients & $\mathrm{T}$ & Sig. \\
\cline { 2 - 3 } & $\mathrm{B}$ & \\
negresi Linier Berganda Model 1 & \\
(Constant) & 7,379 & 5,829 & 0,000 \\
AID & 0,290 & 3,152 & 0,002 \\
SPI & 0,365 & 7,958 & 0,000 \\
PPD & $-0,061$ & $-1,412$ & 0,159 \\
Adjusted R Square & 0,448 & & \\
Regresi dengan Uji Nilai Selisih Mutlak Model 2 & \\
(Constant) & 22,216 & 139,655 & 0,000 \\
Zscore(SPI) & 1,110 & 6,951 & 0,000 \\
Zscore(PTI) & 0,344 & 2,110 & 0,036 \\
Moderasi & 0,487 & 2,275 & 0,024 \\
Adjusted $R$ Square & 0,437 & & \\
\hline
\end{tabular}

Sumber: Data Penelitian, 2020

Dari Tabel 4, dapat disimpulkan bahwa $\mathrm{H}_{2}$ terdukung yang berarti bahwa sistem pengendalian internal berpengaruh positif terhadap akuntabilitas pengelolaan dana desa. Hasil ini menunjukan bahwa Pemerintah Desa di Kabupaten Kulon Progo memperkuat sistem pengendalian internal dengan menetapkan tanggungjawab dan wewenang atas perencanaan pengelolaan secara jelas kepada seluruh perangkat desa untuk mengurangi adanya risiko pelanggaran. Pemerintah desa menindaklanjuti terhadap pertangungjawaban atas 
pelaporan keuangan dengan mengantisipasi potensi kehilangan data arsip keuangan dengan back-up data dan melakukan pemeriksaan terhadap laporan keuangan. Dalam melakukan program-program, pemerintah desa selalu melakukan komunikasi secara terbuka dan selalu ada monitoring serta evaluasi rutin setelah program tersebut dilaksanakan sehingga dapat memberikan tindak lanjut atas penilaian masyarakat maupun inspektorat pemerintahan. Dengan demikian, hal tersebut dapat meningkatkan akuntabilitas pengelolaan dana desa karena keberhasilan dalam penerapan sistem pengendalian internal dapat dilihat dari opini baik dari masyarakat dan BPK yang diterima oleh pemerintah desa di Kabupaten Kulon Progo meskipun masih terdapat masalah yang tidak materil namun tetap perlu adanya perbaikan. Hal ini sejalan dengan penelitian Yudianto \& Sugiarti (2017), Rosyidi (2018), Widyatama et al. (2018), Yesiana et al. (2018), Rezkiyanti (2019).

Dari Tabel 4, dapat disimpulkan bahwa $\mathrm{H}_{3}$ tidak terdukung yang berarti bahwa pelatihan perangkat desa tidak berpengaruh terhadap akuntabilitas pengelolaan dana desa. Hasil yang tidak signifikan ini dikarenakan belum terdapat kejelasan informasi yang diberikan oleh Pemerintah Desa di Kabupaten Kulon Progo berkaitan dengan peningkatan kinerja kepada seluruh perangkat desa. Hal ini menyebabkan pengambilan keputusan untuk meningkatkan kompetensi sumber daya manusia kurang berjalan sebagaimana kondisi yang diharapkan. Pengambilan keputusan untuk peningkatan kompetensi perangkat desa dengan pelatihan bertujuan untuk memaksimalkan pengelolaan dan pemenuhan pertanggungjawaban publik (Bawono et al., 2020). Kondisi peningkatan kompetensi dengan pelatihan belum diadakan untuk seluruh perangkat desa dan mayoritas perangkat desa berlatar belakang pendidikan SMA sehingga pemahaman dasar terkait akuntabilitas masih sangat rendah. Peneliti juga beranggapan bahwa hasil yang tidak signifikan menggambarkan bahwa pelatihan yang diadakan belum didukung dengan informasi terkait kebijakan yang dirancang untuk memberikan pertanggungjawaban pengelolaan yang baik kepada publik. Hal tersebut juga bertolak belakang dengan teori stewardship bahwa pelatihan perangkat desa harus dimaksimalkan dengan memberikan pemfasilitasian pelatihan terhadap perangkat desa. Hal ini dilakukan karena pemerintah selaku steward harus memberikan pertanggungjawabannya secara maksimal kepada masyarakat selaku principal. Hasil penelitian ini tidak sejalan dengan penelitian Arjuna dan Putri (2019), melainkan sejalan dengan penelitian Rangkuti (2018).

Pada Tabel 4, menunjukan hasil analisis regresi linier, maka model persamaan regresi uji nilai selisih mutlak yang dapat dirumuskan adalah sebagai berikut.

$$
\mathrm{APDD}=22,216+1,110 \mathrm{SPI}+0,344 \mathrm{Mo}+0,487\left|\mathrm{SPI}-\mathrm{M}_{\mathrm{O}}\right|+\varepsilon
$$

Pada Tabel 4, menunjukkan nilai Adjusted $R$ Square sebesar 0,437. Artinya variabel Sistem Pengendalian Internal (SPI) setelah dimoderasi Pemanfaatan Teknologi Informasi (PTI) mampu menjelaskan variabel Akuntabilitas Pengelolaan Dana Desa (APDD) sebesar 43,7\% dan sisanya yaitu 56,3\% Dipengaruhi oleh variabel lain yang tidak masuk dalam model penelitian.

Dari Tabel 4, dapat disimpulkan bahwa $\mathrm{H}_{4}$ terdukung yang berarti bahwa pemanfaatan teknologi informasi memperkuat pengaruh positif antara sistem 
pengendalian internal terhadap akuntabilitas pengelolaan dana desa. Hasil ini menunjukan bahwa Pemerintahan Desa di Kabupaten Kulon Progo memberikan prespektif dalam mewujudkan pertanggungjawaban atas pengambilan keputusan yang baik didasarkan pada pemanfaatan teknologi informasi. Pemanfaatan teknologi informasi tersebut merupakan cara steward untuk meningkatkan pengawasan sehingga pertanggungjawaban yang diberikan kepada principal akan maksimal. Pemerintahan dengan sistem pengendalian internal yang baik tetapi tidak didukung oleh pemanfaatan teknologi informasi yang baik maka sistem pengendalian internal yang telah ditetapkan hanya merupakan sebuah prosedur pemerintah yang kurang lengkap (Ahyari \& Ayem, 2019). Keterlibatan perangkat desa dalam penerapan sistem pengendalian internal karena keberhasilan organisasi dalam mengoptimalkan pengendaliannya. Dengan demikian, suatu pemerintahan yang menerapkan pemanfaatan teknologi secara baik dan tepat akan mempengaruhi akuntabilitas pengelolaan dana desa, dimana perangkat desa akan memberikan pertanggungjawabannya secara maksimal demi tercapainya tujuan dan sasaran organisasi. Pemanfaatan teknologi informasi yang diterapkan oleh pemerintah desa pada akhirnya akan memberikan implikasi pada kemudahan memberikan pertanggungjawabannya dengan penggunaan sistem pengendalian internal. Hasil penelitian ini sejalan dengan penelitian Ahyari \& Ayem (2019).

\section{SIMPULAN}

Penelitian ini menguji dan menganalisis pengaruh aksesibilitas informasi desa, sistem pengendalian internal, dan pelatihan perangkat desa terhadap akuntabilitas pengelolaan dana desa dengan pemanfaatan teknologi informasi sebagai variabel moderasi. Hasil yang diperoleh dalam penelitian ini yaitu aksesibilitas informasi desa dan sistem pengendalian internal berpengaruh positif terhadap akuntabilitas pengelolaan dana desa, pemanfaatan teknologi informasi memperkuat pengaruh postif sistem pengendalian internal terhadap akuntabilitas pengelolaan dana desa, dan pelatihan perangkat desa tidak berpengaruh terhadap akuntabilitas pengelolaan dana desa.

Keterbatasan dari penelitian ini yaitu pengambilan data menggunakan proportional stratified random sampling, penelitian ini hanya menggunakan kuisioner yang tidak diikuti dengan wawancara untuk mendetailkan hasil penelitian. Penelitian selanjutnya diharapkan mampu memperbaiki butir-butir pernyataan dalam kuesioner, penelitian selanjutnya sebaiknya apabila menggunakan metode survey dilengkapi dengan teknik wawancara sehingga pengisian kuesioner menjadi lebih akurat dan penelitian selanjutnya dapat menambahkan variabel penelitian yang lain yang sesuai dengan fenomena yang ada pada objek penelitian yang mampu mempengaruhi akuntabilitas pengelolaan dana desa, seperti: Efektivitas Sistem Keuangan Desa (Siskeudes), kompetensi perangkat desa, dan variabel lainnya.

\section{REFERENSI}

Abbaszadeh, M. R., Salehi, M., \& Faiz, S. M. (2019). Association of information technology and internal controls of Iranian state agencies. International Journal of Law and Management, 61(1), 133-150. 
Ahyari, F., \& Ayem, S. (2019). Faktor-Faktor Yang Mempengaruhi Akuntabilitas Kinerja Instansi Pemerintah Dengan Pemanfaatan Teknologi Informasi Sebagai Variabel Moderasi. Jurnal Universitas PGRI Yogyakarta.

Al-Tawil, T. N. (2016). The major issues that need to be addressed by effective corporate governance in the 21st century. Journal of Financial Crime, 23(2), 349378. https:/ / doi.org/10.1108/JFC-01-2015-0003

Alam, M., Said, J., Azizal, M., \& Aziz, A. (2019). Role of integrity system , internal control system and leadership practices on the accountability practices in the public sectors of Malaysia. Social Responsibility Journal, 15(7), 955-976. https://doi.org/10.1108/SRJ-03-2017-0051

Arjuna, \& Putri, A. M. (2019). Akuntabilitas Kinerja Instansi Pemerintah Daerah. Jurnal Akuntansi Dan Ekonomika, 9(2), 223-232.

Azizah, N., -, J., \& Setiawan, A. R. (2015). Penyajian Laporan Keuangan, Aksesibilitas Laporan Keuangan, dan Sistem Pengendalian Internal Pemerintah sebagai Determinan Transparansi dan Akuntabilitas Pengelolaan Keuangan Daerah. Journal of Research and Applications: Accounting and Management, 1(2), 111. https:// doi.org/10.18382/jraam.v1i2.18

Bawono, I. R., Dwi, A., \& Kinasih, M. (2020). Factors Affecting Accountability of Village Fund Management through Implementation of the Village Financial System ( SISKEUDES ). Journal of Accounting and Investment, 21(3), 472-491. https://doi.org/10.18196/jai.2103160

Bernstein, R., Buse, K., \& Bilimoria, D. (2016). Revisiting Agency and Stewardship Theories: Perspectives from Nonprofit Board Chairs and CEOs. Nonprofit Management and Leadership, 26(4), 489-498. https://doi.org/10.1002/nml.21199

Cefrida, M. (2014). Pengaruh Kejelasan Sasaran Anggaran, Pengendalian Akuntansi, Penerapan Akuntansi Sektor Publik Dan Ketaatan Pada Peraturan Perundangan Terhadap Akuntabilitas Kinerja Instansi Pemerintah Kota Pekanbaru. Jurnal Online Mahasiswa Fakultas Ekonomi Universitas Riau, 1(2), 115.

Dewi, N. K. A. J. P., \& Gayatri. (2019). Faktor-Faktor Yang Berpengaruh Pada Akuntabilitas Pengelolaan Dana Desa. E-Jurnal Akuntansi Universitas Udayana, 26(2), 1269-1298.

Donaldson, L., \& Davis, J. H. (1991). Stewardship Theory or Agency Theory: CEO Governance and Shareholder Returns. Australian Journal of Management, 16(1), 49-64. https:// doi.org/10.1177/031289629101600103

Fajri, R., Setyowati, E., \& Siswidiyanto. (2015). Akuntabilitas Pemerintah Desa Pada Pengelolaan Alokasi Dana Desa (Studi Pada Kantor Desa Ketindan, Kecamatan Lawang, Kabupaten Malang). Jurnal Administrasi Publik (JAP), 3(7), 1099-1104. http://administrasipublik.studentjournal.ub.ac.id/index.php/jap/article/v iew $/ 920$

Fauziyah, M. R., \& Handayani, N. (2017). Pengaruh Penyajian dan Aksesibilitas Laporan Keuangan Daerah Terhadap Akuntabilitas Pengelolaan Keuangan Daerah. Jurnal Ilmu Dan Riset Akuntansi, 6(6), 1-16. https://doi.org/10.1017/CBO9781107415324.004

Fikrian, H. (2017). Pengaruh Kualitas Laporan Keuangan, Penyajian Laporan 
Keuangan, dan Aksesibilitas Laporan Keuangan Terhadap Akuntabilitas Pengelolaan Keuangan Daerah. JOM Fekom, 4(1), 265-279.

Haliah, Habbe, A. H., \& Ferdiansah, M. I. (2015). the Role of Information Technology As Moderating Variable and Internal Control Effectiveness As Intervening Variable in the Relationship Between Human Resource Competency and Inter ... (Issue October).

Hasanah, B., \& Sururi, A. (2018). Peningkatan Kapasitas Pemerintah Desa dan Masyarakat melalui Pelatihan Administrasi Pemerintahan di Desa Sukamenak Kecamatan Cikeusal Kapubaten Serang. Forum Ilmu Sosial, 45(2), 94-103.

Hermanto, S. (2019). Laporan Keuangan Terhadap Akuntabilitas Pengelolaan Keuangan Dana Desa ( Survei Pada Desa Di Kecamatan Merapi Timur Kabupaten Lahat Sumatera Selatan ) [Politeknik Negeri Sriwijaya]. https://ejournal.unisba.ac.id/index.php/kajian_akuntansi/article/downlo $\mathrm{ad} / 4928 / \mathrm{pdf}$

Humas BPKP DIY. (2019). Pemda Kulon Progo Siap Meningkatkan Maturitas SPIP. Bpkp.Go.Id. http://www.bpkp.go.id/diy/berita/read/22607/0/PemdaKulon-Progo-Siap-Meningkatkan-Maturitas-SPIP.bpkp

Judarmita, I. N., \& Supadmi, N. L. (2017). Pengaruh Kejelasan Sasaran Anggaran, Sistem Pelaporan dan Audit Kinerja Terhadap Akuntabilitas Pengelolaan Dana Desa. E-Jurnal Akuntansi Universitas Udayana, 21(3), 1719-1746.

Julianry, A., Syarief, R., \& Affandi, M. J. (2017). Pengaruh Pelatihan dan Motivasi Terhadap Kinerja Karyawan serta Kinerja Organisasi Kementerian Komunikasi dan Informatika. Jurnal Aplikasi Bisnis Dan Manajemen, 3(2), 236245. https://doi.org/10.17358/jabm.3.2.236

Kementerian Desa Pembangunan Daerah Tertinggal dan Transmigrasi. (2020). Tentang Indeks Desa Membangun. In idm.kemendesa.go.id. https://idm.kemendesa.go.id/view/detil/1/tentang-idm

Kuntadi. (2019). Kades dan Bendahara di Kulonprogo Jadi Tersangka Penggelapan Dana Desa. Yogya.Inews.Id. https://yogya.inews.id/berita/kades-danbendahara-di-kulonprogo-jadi-tersangka-penggelapan-dana-desa

Mada, S., Kalangi, L., \& Gamaliel, H. (2017). Pengaruh Kompetensi Aparat Pengelola Dana Desa, Komitmen Organisasi Pemerintah Desa, dan Partisipasi Masyarakat Terhadap Akuntabilitas Pengelolaan Dana Desa Di Kabupaten Gorontalo. Jurnal Riset Akuntansi Dan Auditing "Goodwill," 8(2), 106-115. https://doi.org/10.35800/jjs.v8i2.17199

Perdana, K. W. (2018). Pengaruh Kompetensi Aparat Pengelola Dana Desa, Komitmen Organisasi Pemerintah Desa, Partisipasi Masyarakat dan Pemanfaatan Teknologi Informasi Terhadap Akuntabilitas Pengelolaan Dana Desa di Kabupaten Bantul. In Program Studi Akuntansi. Universitas Muhammadiyah. Yogyakarta.

Prayoga, M. (2017). Pengaruh Good Governance, Budaya Organisasi, Gaya Kepemimpinan, Komitmen Organisasi, Dan Pengendalian Intern Terhadap Kinerja Pemerintah Daerah (Studi Empiris- Pada Skpd Kabupaten Pelalawan). Jurnal Online Mahasiswa Fakultas Ekonomi Universitas Riau, 4(1), 90-104.

Purbasari, P. I., \& Yuniarta, G. A. (2020). Pengaruh Kompetensi Sumber Daya 
Manusia , Budaya Organisasi Dan Pemanfaatan Teknologi Informasi Terhadap Pengelolaan Alokasi Dana Desa Di Kabupaten Jembrana. Jurnal Akuntansi Profesi, 11(1), 24-33.

Putri, M. N. F. (2018). Pengaruh Aksesibilitas Laporan Keuangan, Sistem Akuntansi Keuangan Daerah, dan Sistem Pengendalian Intern Terhadap Akuntabilitas Pengelolaan Keuangan Daerah (Studi pada Organisasi Perangkat Daerah (OPD) di Kabupaten Wonogiri). Institut Agama Islam Negeri Surakarta.

Raharjo, E. (2007). Teori Agensi dan Teori Stewardship Dalam Perspektif Akuntansi. Fokus Ekonomi, 2(1), 37-46.

Rangkuti, M. H. B. (2018). Akuntabilitas Kinerja Di Instansi Pemerintah. Jurnal Akuntansi Bisnis \& Publik, 8(2), 1-14.

Rezkiyanti, Y. (2019). Pengaruh Sistem Pengendalian Internal, Pemanfaatan Teknologi Informasi, dan Kompetensi Perangkat Desa. AKMEN Jurnal Ilmiah, 16(1), 17-24.

Rondonuwu, B. C. (2017). Akuntabilitas Kinerja Aparat Dalam Pelayanan Publik Di Kelurahan Sendangan Kecamatan Kawangkoan. Jurnal Eksekutif, 1(1), 111.

Rosyidi, M. (2018). Pengaruh Transparansi, Kompetensi Dan Sistem Pengendalian Internal Terhadap Akuntabilitas Pemerintah Desa Dalam Pengelolaan Alokasi Dana Desa. JOM FEB Riau University, Pekanbaru, Indonesia, 1(1), 1-14.

Seda, L., \& Tilt, C. A. (2020). Disclosure of fraud control information in annual reports as a means of discharging public accountability information. Journal of Financial Crime. https:/ / doi.org/10.1108/JFC-11-2019-0154

Supardi, S. (1993). Populasi dan Sampel Penelitian. Unisia, 13(17), 100-108. https://doi.org/10.20885/unisia.vol13.iss17.art13

Superdi. (2017). Pengaruh Penyajian Laporan Keuangan, Aksesibilitas, dan Sistem Akuntansi Keuangan Daerah Terhadap Akuntabilitas Pengelolaan Keuangan Daerah. JOM Fekon, 4(1), 2015-2029. https://doi.org/10.1017/CBO9781107415324.004

Susanti, R., \& Wardiningsih, S. S. (2014). Peran Celebrity Endoser dalam Memperkuat Pengaruh Perceived Value terhadap Purchase Intention. Jurnal Ekonomi Dan Kewirausahaan, 14(April), 43-54.

Trisaputra, A. (2013). Pengaruh Pemanfaatan Teknologi Informasi dan Pengawasan Keuangan Daerah Terhadap Ketepatwaktuan Pelaporan Keuangan Pemerintah Daerah (Studi Empiris pada SKPD Pemerintah Provinsi Sumatera Barat). Jurnal Akuntansi, 1(3), 1-20. https://doi.org/10.1016/j.bbapap.2013.06.007

Widyatama, A., Novita, L., \& Diarespati, D. (2017). Pengaruh Kompetensi Dan Sistem Pengendalian Internal Terhadap Akuntabilitas Pemerintah Desa Dalam Mengelola Alokasi Dana Desa (ADD). Berkala Akuntansi Dan Keuangan Indonesia, 2(2), 1-20. https:/ / doi.org/10.20473/baki.v2i2.4762

Yesinia, N. I., Yuliarti, N. C., \& Puspitasari, D. (2018). Analisis Faktor yang Mempengaruhi Akuntabilitas Pengelolaan Alokasi Dana Desa (Studi Kasus pada Kecamatan Yosowilangun Kabupaten Lumajang). Jurnal ASET (Akuntansi Riset), 10(1), 105-112. https://doi.org/10.17509/jaset.v10i1.13112

Yudhitaningsih, A. Y. S., \& Safrida, L. (2018). Persepsi Perangkat Desa Mengenai Pelatihan, motivasi, dan Pengelolaan Dana Desa terhadap Kinerja Pemerintah Desa 
(Studi Kasus pada Desa di Kecamatan Sungai Tabuk Kabupaten Banjar Provinsi Kalimantan Selatan).

Yudianto, I., \& Sugiarti, E. (2017). Pengaruh Penerapan Sistem Pengendalian Instansi Pemerintah (SPIP) Terhadap Akuntabilitas Pengelolaan Dana Desa (Survei Pada Desa-Desa di Wilayah Kecamatan Klari, Kecamatan Karawang Timur, Kecamatan Majalaya dan Kecamatan Rengasdengklok Kapubaten Karawang). Jurnal Akuntansi Dan Keuangan, 17(1), 1-18. 